\title{
Traditional Vernacular Buildings, Architectural Heritage and Sustainability
}

\author{
Almantas Samalavičius, Dalia Traškinaitè \\ Department of Architectural Fundamentals, Theory and Art, Vilnius Gediminas Technical University \\ Vilnius, Lithuania
}

Corresponding e-mail: almantsam@yahoo.com

Article info:

Received: 21-12-2020, Revised: 13-04-2021, Accepted: 15-04-2021

\begin{abstract}
The article is focused on vernacular dwellings in different parts of Europe: southern Italy and Lithuania that have their own traditions. The authors note that the attitude towards traditional vernacular architecture has largely changed due to ongoing research in this domain . Nevertheless, despite persistent continuity of traditional architecture, vernacular architecture was affected by the rise and development of modernist ideology that neglected the realm of tradition. The authors discussed some types of vernacular buildings and their relation to local landscape, especially focusing on the traditional vernacular dwelling of Kuršiu nerija (coastal region bordering with Curonian spit and the Baltic Sea). This region was originally an area of fishermen villages and though some of the settlements ceased to exist there are a number of vernacular houses that belong to architectural heritage. The issues of dwellings, authenticity, survival and protection as well as some ambiguous issues of sustainability of traditional dwellings were discussed. The authors concluded by suggesting that multiple assessment perspective should be employed while dealing with vernacular buildings suggesting that buildings of this type can perform functions extending the tourist consumption.
\end{abstract}

Keywords: Tradition, vernacular architecture, architectural heritage, sustainability.

\section{Introduction: Discovering the Value of Traditional Architecture}

The interest in traditional and vernacular architecture as well as traditional city-making has grown considerably in recent decades. The reasons for the current upsurge of this interest are numerous and we are not going to discuss them in detail, except mentioning a few important details. Though there exists a semantic difference between 'traditional' and 'vernacular' architecture, in further discussion we will refer to all these interrelated types as traditional architecture or traditional/vernacular architecture. We will use terms like traditional and vernacular architecture as synonymous in this particular article. Applying the term vernacular in this context, we will draw on the writings of philosopher and historian Ivan Illich who discussed this phenomenon back in the 70's and 80's of the last century. According to Illich, the world vernacular "comes from an Indo-Germanic root that implies 'rootedness' and 'abode'. Vernaculum in Latin was used for whatever was homebread, homespun, home-made, as opposed to what was obtained in formal exchange." (Illich, 2013:31).

In fact, an interest in the so-called traditional/vernacular building, dwellings, and settlements began as early as the 19th century and was largely triggered by the development of anthropology as a new scholarly discipline. The results of early anthropological interest in traditional/vernacular building are well represented by the study of L. H. Morgan (Morgan: 1896).

The Western world became largely intrigued by traditional building in the 1970's, especially after Austrian- American architect and researcher Bernard Rudofsky organized a famous 
exhibition in New York and eventually published a book under the title, Architecture Without Architects (Rudofsky,1964). In the preface to this ground-breaking volume that overviewed the tendencies of the period, Rudofsky stated that

"Architectural history, as written and taught in the Western world, has never been concerned with more than a few select cultures. In terms of space it comprises a small part of the globe Europe, stretches of Egypt and Anatolia - a little more than was known in the second century A.D." (Rudofsky, 1965:2)

This remark was extremely timely and revealing, because until that time Western mainstream architectural history was openly Europocentric, exalting Western/European architectural heritage and continental architectural legacy. Consequently, traditional building of other cultures was regarded as either primitive or inferior to the accomplishments of Western architecture. This particular view was well-demonstrated in a large number of books published before the 1970's.

In his timely book, Bernard Rudofsky also drew his readers' attention to other aspects of this problem, acknowledging that this ignorance of the non-professional, vernacular way of building resulted in the marginalization of dwellings erected by ordinary people. As these buildings were deemed neither aesthetically nor culturally important, they were often left beyond the radar of architectural history, and vernacular architecture was left to decay without even documenting its existence. Rudofsky, however, insisted that

"There is much to learn from architecture before it become an expert's art. The untutored builders in space and time - the protagonists of this show - demonstrate an admirable talent for fitting their buildings into the natural surroundings. Instead of trying "to conquer" nature, as we do, they welcome the vagaries of climate and challenge of topography." (Rudofsky, 1964:3)

Many things have changed since this important pioneering book on non-professional architecture was published. However, proliferation of research into traditional/vernacular architecture during recent decades has provided grounds to question whether architecture without architects has ever existed. His interpretation of vernacular buildings as "architecture without architects" was challenged and this kind of attitude was consequently questioned. Even if one chooses not to apply the title of 'architect' to any early building, there is enough evidence to realize that building architectural structures and settlements is related to professional or at least semi-professional activity in cultural contexts where the category of "architect" does not exist.

And yet, despite certain overcooked statements and inaccuracies, Bernard Rudofsky can be credited for pioneering in the studies of traditional architecture and ways of building that has developed into an important branch of scholarly research since the 1960's.

The later development in the field of traditional architecture studies can be associated with the work of several other research projects, notably Amos Rapoport (Rapoport, 1969), Enrico Guidoni (Guidoni, 1987), and Paul Oliver (Oliver, 1987). The work of professor Nezar AISayyad of California University at Berkeley should be mentioned in this context, as he edited several important books discussing various issues related to traditional architecture and building and its transformations in the contemporary world. (AISayyad, 1989, 2001, 2003).

These collective volumes were in fact the result of Nezar AlSayyad's activities in organizing a focused and important series of conferences on traditions and architecture. During one of these conferences, the International Association for the Study of Traditional Environments (IASTE) came into being in 1988 and continues to convene architectural researchers 
interested in developing the understanding of traditional architecture, building, and city-making . In addition, other professional and academic associations dedicated to the study of traditional/vernacular architecture and building were also established during recent decades. A book On Adam's House in Paradise: The Idea of a Primitive Hut in Architectural History by architectural historian Joseph Rykwert has also contributed to the anthropological understanding of early architectural structures (Rykwert, 1972).

\section{Methods}

The article is based on: a) critical analysis of literature; b) comparative-historical analysis; c) qualitative and quantitative field research conducted to examine some of the examples of traditional/vernacular architecture discussed in the article. Phenomenological approach was also applied in dealing with traditional/vernacular buildings discussed in the article that are understood and interpreted by the authors not as abstractions but as objects studied during encounters involving experience and observation in situ (on the original place).

A quantitative study was conducted during the article's preparation to determine the number of protected residential houses on the Curonian Spit. The selected buildings are grouped by the time of construction and authenticity (authentic, reconstructed). The selection process was based on the historical analysis and the analysis of the development along with the visual materials: illustrations, drawings, historical and current photographs. The analytical-critical method was used to compare the implementation of national and international heritage protection law in new and protected buildings in the UNESCO Heritage Area of the Curonian Spit.

\section{Discussion: Vernacular Buildings, Traditions and Heritage.}

\subsection{Marginalization of Traditional Way of Building}

It is no secret that throughout the last century, Modernism was both the reigning architectural ideology and its aesthetics. Initially aspiring to a new and revolutionary way of imagining and reconstructing the built environment, Modernism had disastrous effects on the human environment, especially cities. The harm of Modernist dogmas' on urban planning, urban design and city-making of the last century was much discussed and documented. Less agreement between architects and historians, however, exists on the impact of the Modern Movement on architecture and its aesthetic, cultural, and social consequences. Nevertheless, it can be argued that among many other things, architectural Modernism became a globally dominating ideology, the language of architecture and its discourse, largely neglecting and marginalizing other ways of understanding and thus restricting the development of traditional architecture and finally reducing it to the status of 'heritage artefact' exclusively. Architectural Modernism went as far as to wage a war on tradition and all and every way of traditional building. The impact of the Modernism of architecture and urbanism was well-summarized by Leon Krier, who noted that

"A mere half-century ago modernist movement claimed to have developed definite solutions to all problems of the built environment. Today, one truth is evident: without traditional landscapes, cities, and values our environment would be a nightmare on a global scale. Modernism represents the negation of all that makes architecture useful: no roofs, no loadbearing walls, no columns, no arches, no vertical windows, no streets, no privacy, no grandeur, no decoration, no craftsmen, no history, no tradition. $<\ldots . .>$ In fact for several years now neomodernists have had to admit that there is no true substitute for the traditional fabric of streets and squares. Nevertheless, they continue to reject traditional architecture with the same obsolete arguments that yesterday completed them to rejects traditional urbanism." (Krier, 2009:87). 
Krier, an outspoken critic of architectural Modernism, has argued on many occasions that the main problem is not architectural Modernism as such, but its hegemony and dominance on the global scale since the second half of the 20th century. He insisted that the biggest damage done by architectural modernism was done when this supposedly novel style started to exercise hegemony over all other ways of building. And yet, according to Krier, the most important question is "no longer who will win the war, but of how to increase quality on all sides by establishing intelligent, democratic competition, a pluralist education, and nonpartisan, effective criticism." (Krier, 2009: 87).

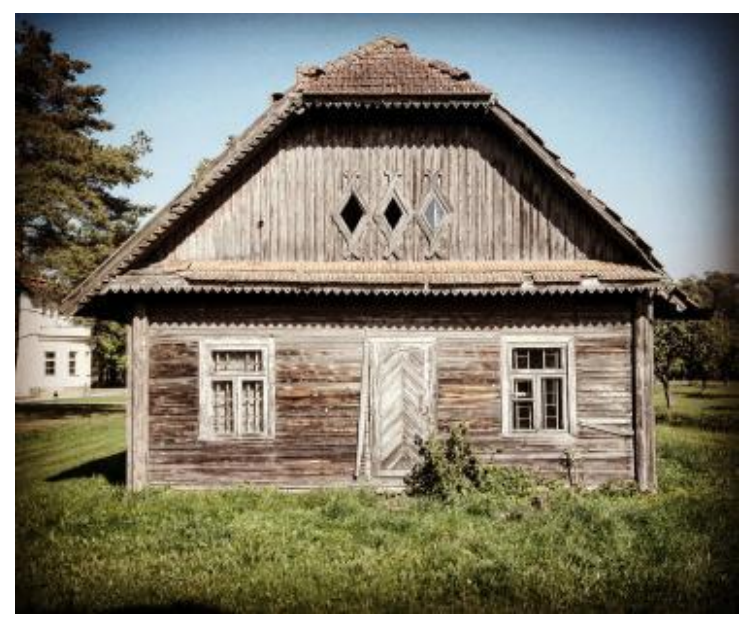

Figure 3.1. Traditional vernacular dwelling, Lithuania. (Photo by A. Gabrènas, 2015)

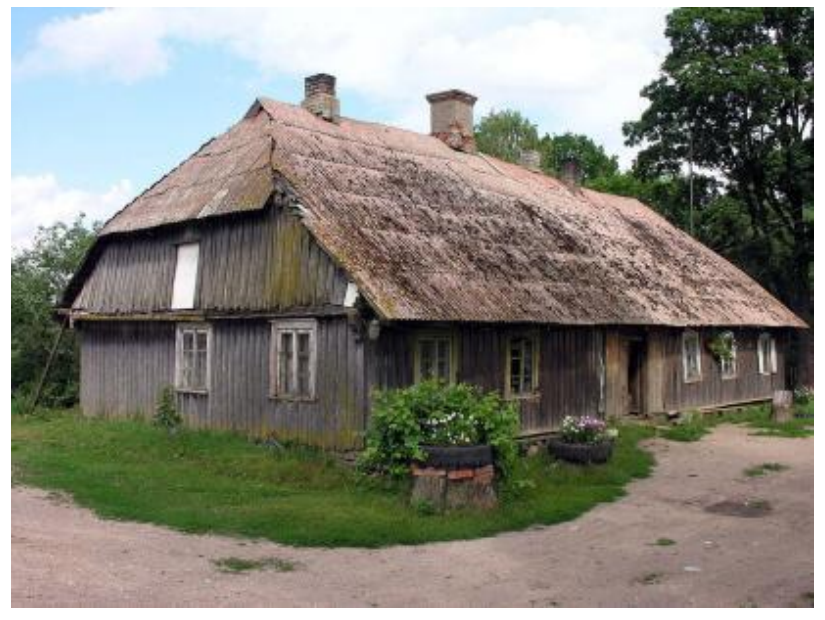

Figure 3.2. Traditional vernacular dwelling in northern Lithuania. (Photo by A. Gabrènas, 2015)

Despite a large period during which architectural Modernism and Post-Modernism dominated globally, certain parallel or even opposing trends have simultaneously emerged in architecture and city-making, and traditional architecture among them. The interest in traditional/vernacular building and settlements was triggered by various factors. At least two reasons for the current upsurge in traditional architecture and urbanism can be mentioned: 1) the growing importance of heritage and rising awareness of the cultural/aesthetic importance of architectural and urban legacy; 2) it is the requirements of sustainability and resilience that contributed to the expanding field of traditional architecture studies with a hope to demonstrate that human beings have attempted to establish a balance with their environment in various historical periods preceding modernity. It is often argued/demonstrated that certain sustainable ways of building have always existed in the history of humanity. Renown architect and architectural theorist Christopher Alexander has dedicated his efforts to prove that human civilization has developed a universal, timeless 'language' of architecture or the concept that he called 'a quality with no name'. (Alexander: 1979). These efforts won him both supporters and critics.

\subsection{Vernacular Dwellings in Southern Italy and Lithuania}

It is well established that each and every culture has its own local traditions as far as dwellings and settlements are concerned. Some of the striking examples of early (primitive) dwellings were presented in Bernard Rudofsky's exhibition and accompanying book. However, no matter how impressive some of these early human dwellings and settlements might be, local traditions of buildings dwellings and urban structures are found all over the globe. 
Within the space allotted to this topic, we would like to discuss a few examples of how local architecture is related to human wisdom as well as responding to issues of sustainability. These examples come from two different parts of Europe: southern and eastern.

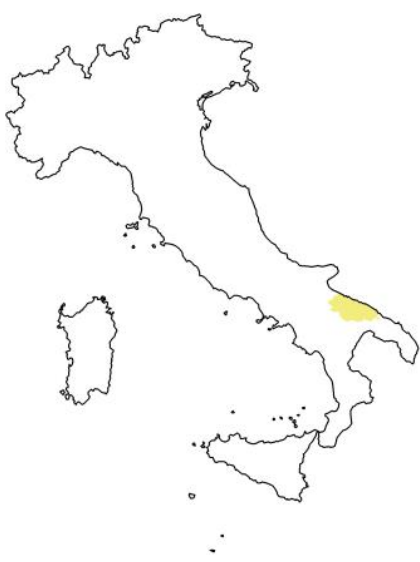

Figure 3.3. Italy, Bari region (Scheme by D. Traškinaitè 2020)

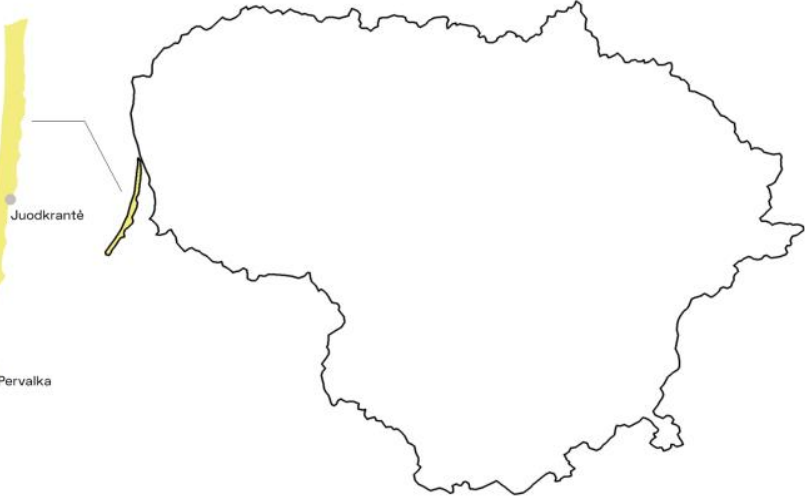

Figure 3.4. Lithuania, Curonian Spit (Scheme by D. Traškinaitè 2020)

a) Vernacular Buildings in Southern Italy: Trullo or Trulli.

Trullo (sing.) or trulli (plural) is a traditional Apulian dry stone hut with a conical roof. Such buildings are found in the region of Apulia (province of Bari), in Southern Italy. The name originates from the Greek word meaning a house whose space is covered by dry stone or a keystone vault. It is important to note that these structures were built without using any mortar or cement. The height of a trullo is from 1,6 to 2 metres. And the buildings belong to traditions of the Mediterranean region that is very old.

These dwellings are known to have existed since the 14th century and were often being used in the 19the century. So far, as many as 1600 dwellings of this type remain - and most of them are located in the city of Alberobello. Originally they were used by peasants and shepherd to stay in with their cattle.

Trullo is a dwelling of a circular or square shape and has few openings, except a small aperture in the roof cone for ventilation.

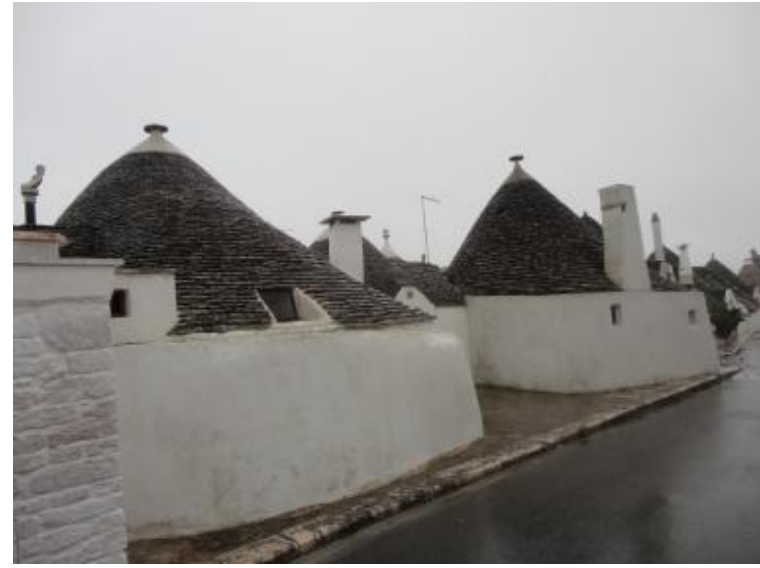

Figure 3.5. Vernacular traditional architecture in Alberobello, Italy.

(Photo by A. Samalavičius, 2018)

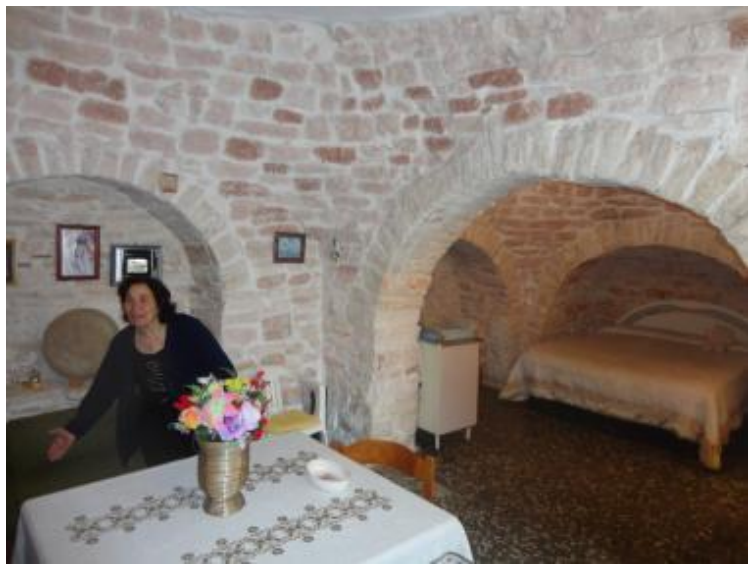

Figure 3.6. Vernacular traditional architecture in Alberobello, Italy.

(Photo by A. Samalavičius, 2018) 
Trulli were almost abandoned in the 20th century but finally were acknowledged as an important part of Apulian architectural heritage and came back to re-use because of cultural tourism. At present, 40 percent of the buildings remain abandoned, 30 percent are for residential use, and the remaining 30 percent for commercial use.

An interesting and important note: these buildings are renown for their adaptability to the local climate. According to the interview conducted by one of the authors of this article with an owner of a trulli in Alberobello, during winter the inside temperature is 10 degrees warmer in comparison with outdoor temperature (without any special heating); meanwhile during summer, the temperature is always 10 degrees lower than outside. Thus the dwellings require no installation of any heating systems. Moreover, the climate in southern Italy is quite mild during the winter season.

\section{b) Vernacular Buildings in Lithuania}

Traditional/vernacular Lithuanian country houses are less impressive than the example of Apulian dwellings provided earlier; however, they represent a culture that adapted to its own climatic conditions. Lithuanian traditional dwelling houses vary in size and planning, yet they are quite moderate in size and were and continue to be built in wood that has been a local material in the region for centuries and millennia. These houses were inhabited by peasants and their families. Unlike Italian trulli, they were used exclusively for humans, as cattle and other provisions for the use of rural families were kept in other specially erected buildings.

Vernacular houses were built using local materials by local, non-professional artisans, mostly carpenters. The works of these builders was not meant to be innovative in any way: on the contrary they mediated knowledge and accumulated information from one generation to another, yet occasionally they improved the usual ways of building (Puodžiukienè 2014:5). Traditional/vernacular architecture developed over the centuries, but it is very difficult to establish the data about origin, moreover so as it was created by local people rather than by professional architects, and records were not kept. The division between vernacular and professional building became more and more noticeable with time. Professional architecture came into being during the period of the Grand Lithuanian Duchy $\left(13^{\text {th }}-18^{\text {th }}\right.$ century), yet traditional/vernacular architecture in its regional varieties continued to dominate for a long time. As Lithuania continued to exist as an agrarian state until World War I, the ethnic building types (vernacular architecture) were the majority of buildings, especially in rural areas. The structure of interior spaces in these rural vernacular houses was established by daily human needs, economic activities, local materials, and the development of building techniques. Every nation that inhabits a particular space usually creates its own peculiar architectural language. Reticence, temperance, simplicity of forms and a harmonious relation to surrounding nature are usually the most accepted features of Lithuanian traditional/vernacular buildings (Purvinas, 2018:3). 


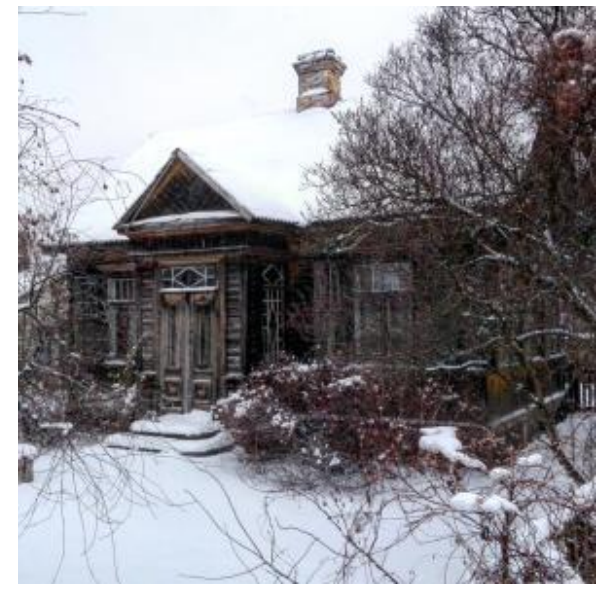

Figure 3.7. Vernacular dwelling in southern Lithuania. (Photo by A. Gabrènas, 2015)

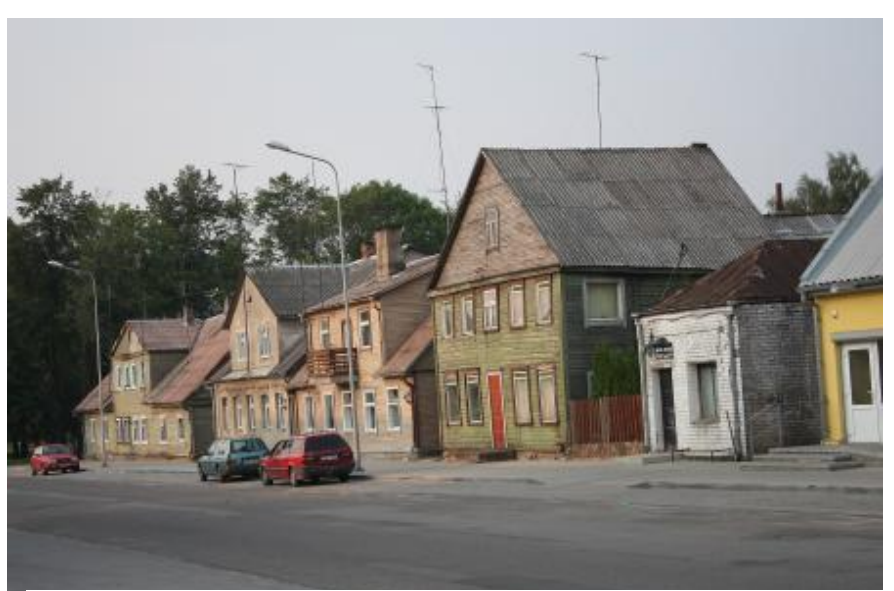

Figure 3.8. Vernacular dwellings in a Lithuanian town. (Photo by A. Samalavičius, 2018)

Climate in Lithuania is very different from Italy: It is much colder in winter, and local dwellings require heating throughout the winter. Thus Lithuanian rural houses were equipped with clay stoves, and wood was/is used to heat these dwellings during winter - which can be quite cold in eastern Europe, occasionally going down to some 10-20 degrees below zero (Celcius).

Unlike trulli that have been recently used as a tourist attraction, Lithuanian rural traditional/vernacular houses continued to be built and used primarily for dwelling purposes though some building elements (e.g. for roofs) have changed. Originally, most roofs were covered with hay or clay tiles, yet currently people prefer more modern, cheaper, and durable synthetic materials.

\subsection{Vernacular Architecture of Kuršių nerija (Curonian Spit)}

Kuršių nerija is a unique natural and cultural area of coastal Lithuania, located between the Curonian Lagoon and the Baltic Sea. Fishermen who inhabited this, established their settlements with predominately wooden vernacular architecture. Because of the natural environment and life in the sandy area, people who inhabited Kuršiu nerija were called people of the dunes. When large areas of trees were cut down in the mid-18th century, and the sand blew over and covered the area on a large scale, the local inhabitants had to move to other parts of the peninsular (Purvinas, 2008: 28). Sandy dunes were strengthened with the help of setting out plants, and since then the settlements have become more stable and grown larger. Professional architecture in the area started in the beginning of the 20th century: these were villas, hotels (first in Juodkrante village, later in Nida village). These new buildings were as a rule adapted to vernacular dwellings, and soon the number of visitors admiring local vernacular dwellings grew considerably - the largely primitive dwellings of the fishermen were an attraction to visitors. (Safronovas 2020: 18) The growing number of visitors had an impact on a change in local dwellings: the amount of decorative details became larger, paint was applied to wooden buildings. The dwellings were built from square beams injected at the corners into a brace (Demereckas, 2011: 8). Their sloping roofs were covered with reed and moss. The principle of contrast was applied to paint: facade plains were painted in dark brown colours and smaller details were either white or blue. 


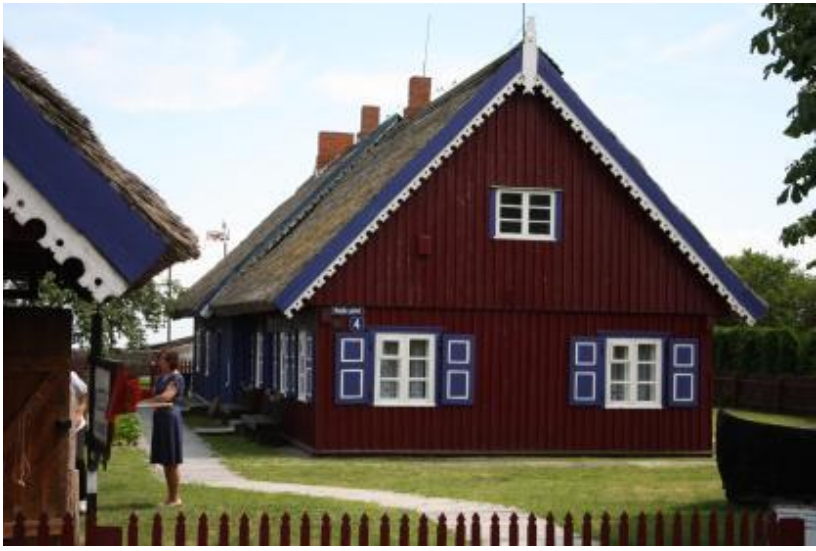

Figure 3.9. Traditional heritage dwelling in Kuršių nerija. (Photo by A. Samalavičius, 2018)

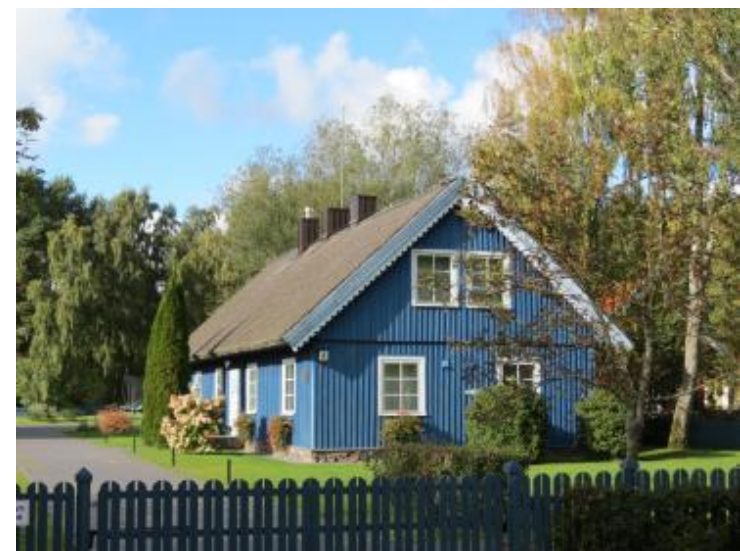

Figure 3.10. Renovated heritage dwelling in Kuršių nerija. (Photo by D.Traškinaitè, 2017)

It should be noted though, that not many original dwellings survived and some of the remaining underwent certain changes because the fishermen's dwelling became an object of scholarly interest rather late, and thus one should be careful when estimating their shape and construction. Most of the buildings now included in the register of Lithuanian cultural heritage were built after 1918 (there are about 70 remaining houses). The rest -27 houses in this region underwent multiple refurbishments in the second half of the 20th century: parts of wooden structures as well as roofing were replaced; interior structures were reshaped and skylighting introduced according to the needs of local tourism. Because of the maritime climate, the dwellings continue to be regularly repainted and their decorative details replaced. Despite attempts to maintain their original look, today many of the vernacular dwellings of Kuršiu nerija have lost some of their authenticity. Moreover, it should be mentioned that throughout the last century many traditional building skills were lost because traditional/vernacular buildings were transformed into objects of cultural heritage rather than living architecture.

The present cultural identity of Kuršių nerija is comprised not only of the surviving vernacular dwellings of fishermen, but also holiday home complexes and the surrounding nature. This area that now has the status of a UNESCO heritage site is made up of "sandy and forested Kuršiu nerija cultural landscape with small coastal settlements came into being due to the interaction of wind and human activity and thus contains unique features of nature and heritage that has social and cultural importance" (UNESCO: 1). It should be added, however, that the identity of the landscape was affected by these new holiday homes that often were larger structures than the dwellings of local fishermen and their environment. Some larger contemporary settlements in this area also contain architectural structures built in the style of Soviet modernism. On the other hand, these buildings represent attempts at regionalism as the architects based their ideas on local vernacular architecture while designing these new structures. Current priorities are based on the discourse of sustainable design, and accordingly the heritage protection policy attempts to preserve a balance between nature and culture, the authenticity of heritage objects as well as unity in the aesthetics of architectural structures and settlements. Some of the older building techniques were preserved, like for example, thatched roofs that continue to be regularly replaced when they wear out, and these techniques contribute to securing the balance between the natural and the built environment. 


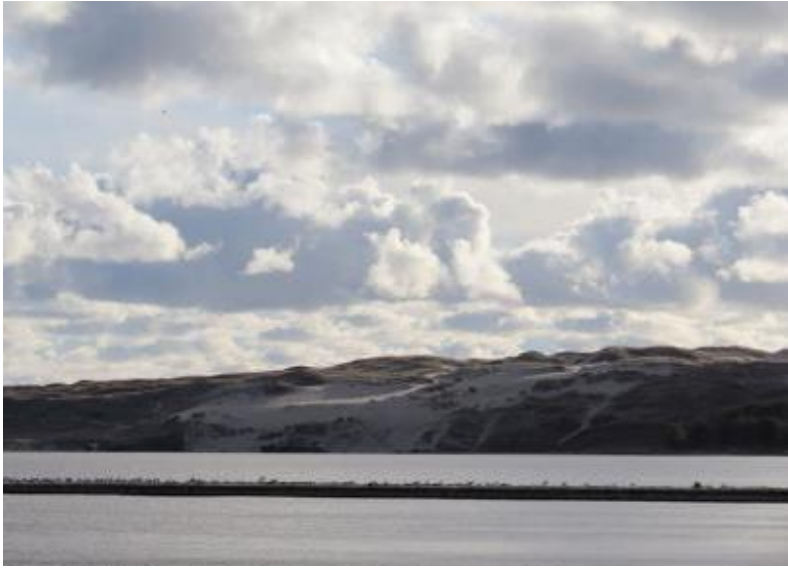

Figure 3.11. Landscape of Kuršių nerija. (Photo by D. Traškinaitè, 2017)

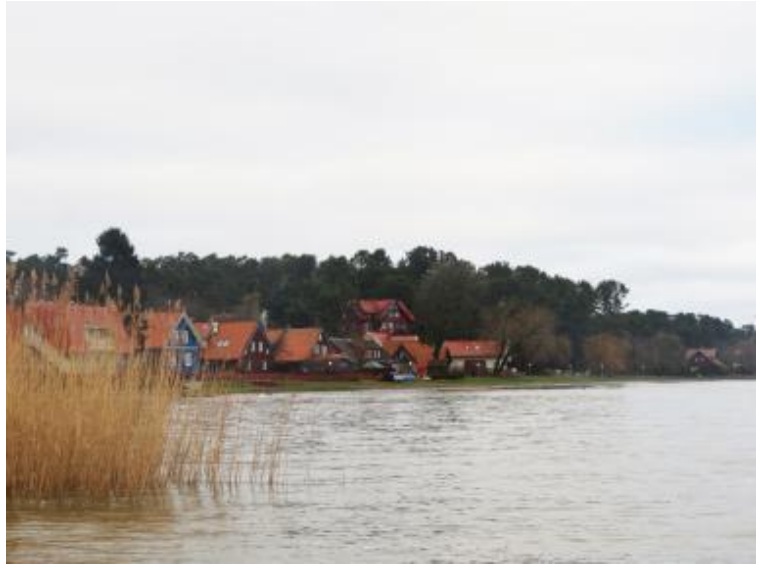

Figure 3.12. Landscape of Kuršių nerija. (Photo by D. Traškinaitè, 2020)

\section{In Conclusion: Vernacular Dwellings and Issues of Their Sustainability}

Discussions whether all traditional/vernacular architecture is sustainable is not new. Some researchers have provided arguments that not all traditional or vernacular buildings were and are sustainable in a technical sense; meanwhile, some have proved to be more sustainable that most contemporary architectural structures built from synthetic materials and consuming large amounts of energy.

For example, there is sufficient evidence that such traditional dwellings as the trulli of Apulian region are sustainable and energy-efficient. (Pietro Stefanizzi et al, 2016). Available evidence suggests that a) humidity in a trullo is more regular than outdoors; b) the temperature is respectively lower and higher in summer than in winter, c) besides, the dwelling does not require artificial/mechanical cooling in summer.

Less evidence on the sustainability issue is available on, say, Lithuanian traditional country houses. They vary in size and type, and most of the surviving ones are historical, as most contemporary structures in the countryside have been subjected to modernization and use different heating systems in winter. Though many contemporary traditional houses copy structural and aesthetic qualities of traditional dwellings, most of them are modernized and thus are not fully traditional in a technical sense.

However, if we approach sustainability of traditional buildings in a broader cultural/aesthetic context than simply emphasizing energy-efficiency, then traditional dwellings can be seen as related to geometry and aesthetics, and current research in neuroscience suggests that aesthetic experience of such structures, rich in formal expression and ornamentation, "is not superficially a 'psychological' aspect, but rather a kind of cognitive 'gateway' allowing us to experience and react to this deeper order of our environment. The artistic dimension lies in the way this gateway is shaped, and in its resonance with other emotional experiences of life.' (Mehaffy and Salingaros, 2015).

Thus traditional/vernacular dwellings, many of which make up architectural heritage, should be assessed using multiple assessment perspectives rather than one or a few technical criteria. Their structural, geometrical, aesthetic as well as decorative qualities were shaped through centuries. Many of such traditional buildings can still provide various functions beyond tourist consumption, as the examples of the Italian stone dwellings trulli and traditional Lithuanian wooden country houses indicate. And last but not least, traditional buildings embody the wisdom of many generations as far as human living space is concerned. 


\section{References}

Alexander C. Et al. (1977). The Timeless Way of Building. New York: Oxford University Press.

AlSayyad, N., Boudier J. P. Eds. (1989). Dwelling, Settlement and Tradition.

AlSayyad, N. Ed. (2001) Consuming Tradition/Manufacturing Heritage: Global Norms and Urban Forms in the Age of Tourism. New York: Routledge

AlSayyad, N. Ed. (2003) The End of Tradition? New York: Routledge

Demereckas K. (2011). "Kuršių nerijos tradicinè architektūra", In: Kuršių nerijos tradicinè architektūra, Kęstutis Demereckas, Ed. Klaipėda: Libra Memelensis.

Guidoni, E. (1987) Primitive Architecture. New york: Rizzoli.

Illich, I. (2013). Beyond Economics and Ecology: The radical Thought of Ivan Illich. Edited by Sajay Samuel. London: Maryon Boyars

Krier, L. (2009). The Architecture of Community. Washington: Island Press.

Kultūros paveldo registras. Internet sources URL https://kvr.kpd.It/\#/static-heritage-search

Mehaffy M, Salingaros N. (2015) Design for a Living Planet. Portland: Sustasis.

Morgan, L. H. (1896). House and Houselife of American Aborigenes. Chicago: University of Chicago Press.

Puodžiukienè, D. et al., Ed. (2014). Lietuvos architektūros istorija. T. IV. Vilnius: Savastis.

Purvinas, M. (2008). Mažosios Lietuvos tradicinè kaimo architektūra. Vilnius: Etninè skultūros taryba.

Purvinas, M. (2018). "Lietuvos etninè architektūra - paveldas ir apibūdinimai“, In: Kultūros paminklai, Vol. 22.

Oliver P. (1987). Dwelling: The Vernacular House Worldwide. University of Texas Press.

Rykwert, J. (1972). On Adam's House in Paradise: The Idea of the Primitive Hut in Architectural History. New York: The Museum of Modern Art.

Rudofsky, B. (1965). Architecture Without Architects: A Short Introduction into Non-pedigreed Architecture. New York: The Museum of Modern Art.

Safronovas V. (2020). "Nerija iki Neringos: trumpa gyvenviečių istorija", In: Neringa: Architektūros gidas, Marija Drèmaitè et al. Vilnius: Lapas.

Stefanizzi, P. et al. (2016). "Energy and Environmental Performance of trullo Stone Building. An Experimental and Numerical Survey, conference paper, June 2016. www.researchgate.net.publication/304735087

UNESCO. Outstanding Universal Value of the Curonian Spit. Description Internet sources URL https://whc.unesco.org/en/list/994 